\title{
Types of English Determiners Accordıng to Their Position
}

\author{
Shalala Anver Aliyeva \\ $\mathrm{PhD}$, Senior lecturer of English Grammar Department \\ Azerbaijan University of Languages, Baku, Azerbaijan \\ Rashid Behbudov street 134. AZ1014. Baku, Azerbaijan \\ Tel: +994505311599 E-mail: shalalahaliyevah@gmail.com
}

\begin{abstract}
The article deals with determiners and their types according to the position in English. Here, viewpoints of different linguists have been looked through. In the article we disscussed the problem of functions of determiners and the notions they express in a language such as definiteness and indefiniteness.

Besides, the articles touches upon the types of determiners according to their position in a sentence or a combination. Here, 3 types of determiners - pre-determners, central determiners and post-deerminers are analysed.
\end{abstract}

The article also clarifies the difference between general and special determiners in Modern English.

Key words: determiners, pre-determiners, central determiners, post determiners, noun phrase, modification

DOI: $10.7176 /$ JLLL/65-07

Publication date: February $29^{\text {th }} 2020$

\section{INTRODUCTION}

By determiner (noun determiner) in English, the words which are used in front of the nouns are meant. In Modern English, most nouns are used with determiners (modifiers).

In modern world, though there is observed great interest in the investigation of determiners, most of their features haven't been investigated yet. The general viewpoint of the investigation of determiners is that determiners exist in all languages. The diverse opinions about the investigation of determiners in linguistics relate to their classification, semantic and syntactic features and also the role that they play in a sentence.

When analyzing determiners, many linguists refer to their function a language system, while others talk about distributive criteria. In Modern English, whenever one hears the word "determiner", he/she recalls immediately articles. And some linguists say that by determiner, all helping words which can act in the position of articles are meant.

Famous English linguist and methodologist H.Palmer joins under the term of "determiner" all adjectivepronouns which don't describe nouns but only modify them. It should be noted that the term "determiner" is derives from the verb "to determine" in English. Like H.Palmer, American linguist Ch.Fries calls all the words determiners which are used in the position of articles. He puts articles, numerals, demonstrative and possessive pronouns, and also the pronouns denoting quantity such as "some", "any" into a determiner class. According to Ch.Fries, determiners are the words that can substitute articles. [Alekseeva, 2009].

L.Blumfield considers determiner a type of adjectives. He divides determiners into two large groups: descriptive and limiting. The limiting adjectives are also subdivided inro two groups by him: determiners and numeratives [Alekseeva, 2009]. Opposing to L.Blumfield, P.Roberte va U.Fransis refer determiners to adjecitives, but like Ch.Fries, he agrees with the point that they are helping verbs which can be used instead of articles [Alekseeva, 2009].

According to russian lnguist A.I.Smirnitsky, articles are adjective-pronouns having not full but partial meaning. The scientists think that though adjective-pronouns differ from articles for the meaning they express, they are alike for their functions. The scholar rightly considers that both articles and adjective-pronouns are nounmodifiers, and regulators. For example, not depending on how we pronounce the word house, it wil have the 
meaning of home/house, which means the building for living. If we pronounc eit like the house or any house, the situation will be somehow different. When we pronounce the house, we will mean a concrete house, but when we use any house we will mean no matter which house. In this meaning we agree with the opinion of O.V.Yakovenko that determiners for their meaning are regulators, operators of the situation[http://elar.usfeu.ru/bitstream/123456789/6314/1/inyaz-2014_11.pdf]. P.Harder's article dealing with

"the matching of functional and formal approaches to determiners in linguistics" has attracted the attention of many linguists. P.Harder in the article "Determiners and definiteness: functional semantics and structure differentiating" noted that functional and formal approach to determiners gives bases to speculate that structural and semantic categories often match or coincide. The author tries to prove that, determiners' categories consist of different elements. P.Harder being the followers of functionalism, his approach has been given in a simple way [Harder P. 2008].

One of the debatable moments of determiners is that they are considered a separate part of speech. So, in traditional grammar which takes its bases from greek grammar, the article was considered one of the 8 main classical parts of speech. N.Chomsky's generative grammar gave a push to the development of this idea. N.Chomsky's theory notes the importance of the specificator in a sentence. In noun phrases it is realised by the help of determiners [Alekseeva, 2009].

\section{METHODS}

The current article discusses the determiners and some features of it. So, to reveal some features, linguistic analysis method is widely used in the article, which helped to analyze the given topic in details. Here, some viewpoints of specialists are analyzed. In some cases, to give a detailed description to some notions some translations are given in Azerbaijani, which proves the slight use of comparative method.

\section{MATERIALS OF THE RESEARCH}

\subsection{Functions of determiners in English}

A russian linguist V.G.Gack develpoed the idea that determiners should be put into a separate part of speech on the bases of semantic, morphological and syntactical features. He notes 3 functions of determiners as a separate part of speech:

1) Syntactical function: determiners function in a sentence as a main actualizator of a noun. The role of determiners in the creation of syntactical constructions in a sentence cannot be denied.

2) Morphological function: in case there is not a special form (flective languages) governing morphological case and number categories of a noun, determiners perform this function easily.

3) Semantic function: according to V.G.Gack, determiners' semantic function reveals in the expression of grammatical categories such as definiteness - indefiniteness, known - unknown.

In many languages in nominal phrases an element which has the function of proving the definiteness and indefiniteness of that phrase, is used. In Modern English though the main means of expression of definiteness and indefiniteness is considered article $(\mathrm{a} / \mathrm{an}-\mathrm{the})$, it has other means of expression too. E.g:

In the phrase this building "bu bina" demonstrative pronoun this expresses definiteness, while in the expression $a$ several buildings "bir neçə bina" a several expresses indefiniteness.

Russian linguist V.G.Gack considers that determiners express general characteristics of the object - its definiteness, number, possession, etc. [Gack, 1986]. There is a serious diversity of opinions among linguists on what level determines belong to. Thus, some linguists put articles, pronouns, numerals into determiners, while others don't accept this viewpoint. In 1985 in a grammar book published in London, it was noted that English determiners include 6 classes of language units: articles (of definiteness and indefiniteness), demonstrative and possessive pronouns, words denoting number (quantitative words), cardinal and ordinal numerlas.

V.G.Gack's french grammar book, determiners include 5 semantic-grammatical classes of language units. They are articles, possessive, demonstartive, interrogative and indefinite determiners [Harder, 2008]. So, article is put 
into both classifications, as it expresses definiteness and indefiniteness. According to Russian linguist O.I.Moskalskaya's point of view determiners express possession, belonging, demonstrativeness, indefiniteness and total plurality and that's why they regularly accompany nouns as an element of the word-stock of a language [Moskalskaya, 1953]

\subsection{Notions that determiners express in a language}

Usually, determiners are divided into 2 groups: definiteness and indefiniteness. Determiners expressing definiteness are: article the, demonstartive and possessive pronouns, determiners expressing indefiniteness are article of indefiniteness a/an, words denoting quantity (quantificators), wh-determiners, adjective-numerals.

Category of definiteness and indefiniteness is one of the debatable problems in modern linguistics. The main purpose of the linguists investigating this problem is to determine the main criterion of the category of definiteness.

Some terms like uniquness, definiteness, unique identification and extension are usedas a criterion of definiteness. Among them extension is considered to be the most suitable one for the defniteness category, because it contains some features like definiteness, uniqueness. Extension theory was founded by D.Lewis, and he thinks that when we say The door is open "Qapı açıqdır" we don't mean the only open door, but the nearest door in the process of communication. The factors such as the recall of the previously known object, speakers standing near that object and pointing at it can also cause extension, however all these are not enough. Here the mental, cognitive factor which can supply of the speaker with appropriate information, is very important [https://cyberleninka.ru/article/n/o-bazovoy-harakteristike-angliyskih-determi-nativov].

So, determiners show that the words they modify are nouns. In comparison with adjectives, determiners neither describe nouns, nor give extra information about them. These words show some characteristics of nouns (singular - plural, definite - indefinite, etc.). Determiners, usually, are used in front of nouns and noun phrases. If there are other words characterising nouns, determiners are used in front of them. E.g. her writing skills "onun yazı vərdişləri”".

The use of determiner in front of any word (verb, adjective, adverb), shows that it is a noun. E.g. five (beş numeral) - a five (beş qiymət); to dream (arzulamaq - verb) - a dream (arzu, xəyal, yuxu); green (yaşıl adjective) - the green (göyarti); many (çox) - the many (bir çoxları);

Thus, determiners include:

1. Article - definiteness (the) and indefiniteness ( $\mathrm{a}$, an);

2. Possessive pronouns (my, your, his, her, its, our, your, their);

3. Demonstartive pronouns - this ( $\mathrm{bu}$ - singular form), these (bu - plural form), that (o - singular form), those ( o - plural form), such (belə), the same (eyni, həmin);

4. Interrogative pronouns - what? which? (hans1), whose? (kimin);

5. Indefinite pronouns - some (bəzi, bir neçə), any (bəzi, bir neçə -interrgative and negative);

6. Defining pronouns - all (hamı, bütün), both (hər ikisi), every (hər) each (hər), other (başqası), another (digəri), either (hər ikisi, ikisindən biri);

7. Negative pronouns - no, none (heç biri);

8. Words denoting number (quantity) - many, much, few, a few, little, a little;

9. Nouns used in the possessive case. Sometimes these nouns are also preceded by determiners. E.g. an engineer's directions.

10. Numerals - cardinal numerals - two, three; ordinal numerals - third (the third) .

\section{Findings and Analysis of determiners}

\subsection{Theoretical division of determiners in English}

L.S.Barkhudarov talking about determiners, claims that an article and another determiner cannot be used in front of nuns at the same time. [Alekseeva, 2009]. L.S.Barkhudarov doesn't accept the words used in front of noun phrases (pre-determiners) and after the noun determiners (post-determiners) as determiners and there is no unity of opinions among the linguists on it. So, R.Quirk's grammar, determiners such classification as below attracted 
the attention of many western linguists. According to him, in Modern English determiners are divided into 3 groups:

1. Pre-determiners;

2. Post-determiners;

3. Central determiners [Quirk et al, 1985]

The author thinks, a (an), the, this, that, these, those, my, whose, what and others are central determiners, since thay are used directly before the word they determine. However, in most cases central determiners are followed by post-determiners. E.g:

* those three years

* the many books (I read)

* the first two years

In the above given examples, the determiners in bold are central ones, but the elements following them in italics are post - determiners.

R.Qurik in "Grammar of the English Language" book used such pronouns as all, both as a pre-determiner. E.g:

* all the solutions;

* both those pages;

In these examples the words in italics - all and both are pre-determiners, the and those are central determiners. All these three determiners can be used at the same time. E.g.

all the many hours (that we have spent).

In these examples all is a pre-determiner, the is a central determiner, many is a post-determiner. In some cases 4 determiners can also occur at the same time. E.g. all the many such possibilities "bütün bu imkanlar çoxluğu". In these examples all and such are pre-determiners, the - is central determiner, many - is a post-determiner [Quirk et al, 1985].

\subsection{Central determiners in English}

Central determiners are very necessary in comparison with other determiners, since they cover (include) articles and their usage in front of nouns is very important. There is no possibility of the occurence of two central determiners at the same time. Centra determiners usuually precede the nouns or nominal elements they modify. If adjectives, participles or nouns in the function of attribute are used in front of these nouns or nominal phrases, central determiners preced them. E.g.

A sad scene - qamgin sahna, the sold book - satılmış kitab, a car crash-avtomobil qazasi. 
Central determiners include the followings:

\begin{tabular}{|c|c|}
\hline Article of Definiteness or Definite Article & The \\
\hline $\begin{array}{l}\text { Article of Indefiniteness or Indefinite } \\
\text { Article }\end{array}$ & $\mathrm{A} / \mathrm{an}$ \\
\hline Demonstrative Pronouns & $\begin{array}{l}\text { This (bu - singular form), these (bu - plural form, } \\
\text { that (o- singular form), those (o-plural form) }\end{array}$ \\
\hline Possessive Pronouns & $\begin{array}{l}\text { My-mənim, your - sənin, his - onun, her - onun, its } \\
\text { - onun, our - bizim, your - sizin, their - onların. }\end{array}$ \\
\hline Interrogative Pronouns & $\begin{array}{l}\text { What - What day is it? Bu gün həftənin hansı } \\
\text { günüdür? } \\
\text { Whose - Whose book is it? Bu kimin kitabıdır? } \\
\text { Which - Which book should I read? Mən hansı kitabı } \\
\text { oxuyum? }\end{array}$ \\
\hline Relative Pronouns & $\begin{array}{l}\text { Whose - This is the student whose book I am } \\
\text { reading. Bu kitabını oxuduğum həmin tələbədir. } \\
\text { Which - This is the book which I bought yesterday. } \\
\text { B mənim dünən aldığım kitabdır. } \\
\text { Whichever - It's a long trip whichever road you take. } \\
\text { Hansı yolla getsən bu uzun səyahətdir. } \\
\text { Whatever - You can use it for whatever purpose you } \\
\text { wish. Sən bunu istədiyin bütün məqsədlər üçün } \\
\text { istifadə edə bilərsən. }\end{array}$ \\
\hline Indefinite Pronouns & $\begin{array}{l}\text { Some (bəzi, bir-neçə - in affirmative sentences, any - } \\
\text { in negative and interrogative sentences). }\end{array}$ \\
\hline Negative Pronouns & No (heç bir), neither (heç biri) \\
\hline Defining Pronouns & Every (hər), each (hər bir), either (ikisindən biri). \\
\hline
\end{tabular}

1) They took him with them to all the many addresses. "Onlar onu özləri ilə bütün çoxsaylı ünvanlara apardılar".

2) If even half these 24 MPs are declared bankrupt the Government could lose its majority. "Ogər bu 24 deputatın yarısı müflis elan edilsəydi, hökumət çoxluğu itirmiş olardı".

3) He kept the highest standards in all his many roles. "O, özünün bütün çoxsaylı rollarında ən yüksək standartlara riayət edirdi".

In these samples the, these, his are central determiners, all, half are pre-determiners, and many iso postdeterminer.

\subsection{Pre-determiners in English}

Central determiners can also be preceded by modifiers and such determiners are called pre-determiners. The followings belong to pre-detrminers:

All - all these children - bütün bu uşaqlar

Both - both the boys - oğlanların har ikisi 
Double-double the number-iki dafa çox

Twice - twice a day - gündə iki dafa

Half-half a loaf-yarım kömbə

Such - such a girl - ela quz

What - What a fine day it was! Bu ela gözal gün idi ki!

We should note that defining pronoun all and demonstrative pronoun such can be used without central determiners. In this case the meaning they express will be connected with the idea of indefiniteness, but not definiteness.

E.g. All the girls - bütün quzlar (the girls who are known to the speaker) - all girls (all girls in general, not the ones whom we know).

a) All the girls are ready to meet their parents. "Bütün qızlar valideynlərini qarşılamağa hazırdır" (Here they talk about the girls in the class or course).

b) All girls like such dresses. "Bütün qızlar belə paltarları xoşlayır". (Here girls are meant not in concrete meaning, but in general meaning.

One of the izomorphic features of the determiner "such" is that in front of it another pre-determiner, central determiner and even post determiner can be used. Compare:

1. All such books - belo kitablarin hamist. In this example, another pre-determiner (all) is used before predeterminer such.

2. No such jokes - belə zarafatların heç biri (никаких подобных шуток). İn this sentence "no" central determiner is used in front of such pre-determiner.

3. Many such jokes - Bu zarafatların çoxu. Here, we see post-determiner "many" which preceded pre-determiner such.

\subsection{Post-determiners in English}

Post-determiners, as a rule, are followed by central determiners. They include the followings:

1. Numerals or numbers (cardinal or ordinal numerals) - those two problems "o iki problem", my first job "mənim birinci (ilk) ișim;

2. Words denoting quantity or quantificators (many, several, little, few); E.g.: your many kindnesses "sizin böyük lütfükarlığınız", his several attempts "onun bir-neçə cəhdi", the few possessions he owned "onun malik olduğu bir neçə əmlak" and so on.

It should be notes that some post-determiners can be used without post-determiners, too. E.g.

When I entered the room I saw two girls sitting at a table."İçəri daxil olanda mən iki q1zın stol arxasında əyləşdiyini gördüm".

1) No one can be blamed for the many errors of fact. "Faktın bir çox nöqsanlarında heç kim günahlandırıla bilməz".

2) The few survivors staggered bleeding back into camp. "Sağ qalmış bir-neçə adam qanı axa-axa düşərgəyə qayıtdı".

3) So why do his words carry such little weight? "Nə üçün onun sözləri kifayət qədər kəsərli deyildir?"

4) I need to sell these four boxes of fruit. "Mən bu dörd qutu meyvani satmalıyam". In the above-given examples $(1,2,4)$ the and these are central determiners, such is pre-determiner, many, few, little, four are post-determiners. 
Determines (Determinatorlar) fall under two types: general determiners and special (specific) ones [https://grammarianism.wordpress.com/tag/postdeterminer].

Special (specific) determiners: They are used when the speaker and the listener both know concretely what object or a person is spoken about. Special (specific) determiners include the article of definiteness "the", demonstrative and possessive pronouns.

\begin{tabular}{|l|l|}
\hline $\begin{array}{l}\text { The article of } \\
\text { definiteness }\end{array}$ & «the» \\
\hline Demonstrative article & $\begin{array}{l}\text { «that» (o - singular form), «this» (bu - singular form) «those» (o - plural form) } \\
\text { «these» (bu - plural form) }\end{array}$ \\
\hline Possessive pronouns & $\begin{array}{l}\text { «my» (monim), «his» (onun - masculine gender) «her» (onun - feminine gender), } \\
\text { «your» (sənin, sizin), «our» (bizim), «its» (onun - inanimate things), «their» } \\
\text { (onların). }\end{array}$ \\
\hline
\end{tabular}

*The dog barked at the running boy. "İt qaçan oğlana hürdü”. - Here the concrete object of the conversastion is the boy running, i.e. the object is known or definite.

*Those cherries are rotten. "O albalılar çürükdür". - In this example the demonstrative pronoun points at the very cherries that are rotten, not the others.

*Our train was late. "Bizim qatarımız gecikmişdi". This sentence has the determiner having the meaning of possession or belonging.

General determiners: The objects or the persons that general determiners modify, can be in indefinite numbers and quality. The table below shows the examples on general determiners [http://www.dslib. net/germanskiejazyki/kognitivno-seman-ticheskie-svojstva-determinativov-v-anglijskom-jazyke.html].

\begin{tabular}{|l|l|l|l|}
\hline \multicolumn{3}{|c|}{ Indefinite article "a" and "an" } \\
\hline $\begin{array}{l}\text { few (az) (used with some countable } \\
\text { nouns) }\end{array}$ & both (hər iki) & $\begin{array}{l}\text { other (başqa, } \\
\text { digər) }\end{array}$ & any (istənilən) \\
\hline $\begin{array}{l}\text { less (nisbətən az) (used with } \\
\text { ucountable nouns) }\end{array}$ & each (hər) & neither (heç bir) & all (hamı, bütün) \\
\hline $\begin{array}{l}\text { many (çox) - (used with some } \\
\text { countable nouns) }\end{array}$ & every (hər) & no (heç) & another (digəri) \\
\hline $\begin{array}{l}\text { much (çox) used with some } \\
\text { uncountable nouns) } \\
\text { biri) (ikisindən }\end{array}$ & $\begin{array}{l}\text { some (bəzi, bir } \\
\text { neçə) }\end{array}$ & $\begin{array}{l}\text { a few (bir az) used with some } \\
\text { countable nouns }\end{array}$ \\
\hline $\begin{array}{l}\text { most (əksəriyyət, çoxluq) } \\
\text { qədər) (kifayət }\end{array}$ & $\begin{array}{l}\text { several neçə) } \\
\text { nore (daha çox) } \\
\text { fewer (daha az) used with some } \\
\text { countable nouns }\end{array}$ & $\begin{array}{l}\text { attlle (bir qədər) used with some } \\
\text { uncountable nouns }\end{array}$ \\
\hline
\end{tabular}

So, determiners are inseparable part of all languages and they have different divisions and classifications in different languages. 


\section{CONCLUSION}

As a conclusion, it should be noted that, the problem of determiner in English is an interesting but debatable matter. After analyzing different viewpoints of Russian and Western linguists such as A.I.Smirnitsky, V.G.Gack, L.S.Barkhudarov, R.Quirk, D.Lewis, H.Palmer, L.Blumfield, etc. their theories on determiners and classifications were analysed. Western linguists' divisions of language elements called determiners into 3 main types according to the position is the most necessary part of the article and is considered to be a valuable contribution to the linguistics, linguists and investigators.

\section{REFERENCE}

Алексеева М.Е. (2009). О проблеме детерминативов в контексте современных синтаксической теорий, Вестник Санкт-Петербургского Университета, сер. 13, вып. 1, С. 107-113. (Alekseeva M.Е. (2009). On the problem of determiners in the context of modern syntactical theories)

Гак В.Г. (1986). Теоретическая грамматика французского языка. Ч. 1. 2-е изд. Москва, стр. 87-89. (Gack V.G. (1986). Theoretical grammar of French)

Москальская О.И. (1953). Развитие артикля в древних германских языках. (автореф.дисс...доктора филол. наук) Моск. воен. инст-т ин языков, Москва, (Moskalskaya O.I. (1953). Development of article in ancient germanic languages)

Harder P. (2008). Determiners and Definiteness. Functional semantics and structural differentiation// essays in nominal determination/ from morphology to discourse management / Ed. By H.H.Miller, A.Klinge, Amsterdam, pp. 1-27

Quirk R., Greenbaum S., Leech G., Svartvik J. (1985). A Comprehensive Grammar of the English Language, London: Longman, $1779 \mathrm{pp}$.

Web pages:

http://elar.usfeu.ru/bitstream/123456789/6314/1/inyaz-2014_11.pdf

http://www.dslib.net/germanskie-jazyki/kognitivno-semanticheskie-svojstva-determinativov-v-anglijskomjazyke.html

https://cyberleninka.ru/article/n/o-bazovoy-harakteristike-angliyskih-determinativov

https:/grammarianism.wordpress.com/tag/postdeterminer/ 